\title{
Neurofibromatosis tipo I con manifestaciones en el periodonto y lengua: presentación de un caso
}

\author{
Type I neurofibromatosis with periodontal and lingual manifestations: \\ a case report
}

\author{
M.C. Negreiros Lyrio', F.R. Loureiro Sato², H. Montagner 3 , J.L. Muñante Cardenas 4 , M. de Moraes ${ }^{5}$
}

Resumen: La enfermedad de Von Recklinghausen o Neurofibromatosis Tipo I (NF1) es una condición autosómica dominante que presenta una variada expresión clínica, con manifestaciones que van desde manchas tipo café con leche en piel a severas complicaciones estéticas y funcionales afectando los tejidos óseos y nerviosos. Las manifestaciones orales de la NF1 son comunes, afectando aproximadamente al $72 \%$ de los pacientes. Presentamos un caso de NF1 con lesiones neurofibromatosas afectando al reborde alveolar inferior y lengua, con indicación de excisión quirúrgica debido a la dificultad de higiene local.

Palabras clave: Neurofibromatosis; Enfermedad de Von Recklinghausen; Hiperplasia gingival; Lengua.

Recibido: 05.11.2007

Aceptado: 07.03.2008
Abstract: Von Recklinghausen's disease, or type I neurofibromatosis (NF-1), is an autosomal dominant condition with a varied clinical expression. Disease manifestations may range from café au lait spots of the skin to severe cosmetic and functional complications that affect bone and nervous tissues. Oral manifestations of NF-1 are common, affecting approximately $72 \%$ of patients. We report a case of NF-1 with neurofibromatous lesions of the lower alveolar bridge and tongue. Resection was indicated due to the difficulty of maintaining oral hygiene.

Key words: Neurofibromatosis; Von Recklinghausen's disease; Gingival hyperplasia; Tongue.

1 Alumna de Maestria en Cirugía y Traumatología Buco-maxilo-facial de la Faculdad de Odontología de Piracicaba - Universidad Estadual de Campinas (FOP-UNICAMP)

2 Alumno de Maestria en Cirugía y Traumatología Buco-maxilo-facial de la Faculdad de Odontología de Piracicaba - Universidad Estadual de Campinas (FOP-UNICAMP)

3 Cirujano-Dentista, pasante del Área de Cirugía y Traumatología Buco-maxilo-facial de la Faculdad de Odontología de Piracicaba - Universidad Estadual de Campinas (FOP-UNICAMP)

4 Cirujano-Dentista, pasante del Área de Cirugía y Traumatología Buco-maxilo-facial de la Faculdad de Odontología de Piracicaba - Universidad Estadual de Campinas (FOP-UNICAMP)

5 Profesor Asociado del Área de Cirurgía y Traumatologia Buco-Maxilo-Facial. Facultad de Odontología de Piracicaba - Universidad Estadual de Campinas (FOPUNICAMP)

\section{Correspondencia:}

Márcio de Moraes

Avenida Limeira, $n^{\circ} 901$ - Caixa Postal 52

13414-903 Areião, Piracicaba/SP

Email: mmoraes@fop.unicamp.br 


\section{Introducción}

El término neurofibromatosis (NF) es usado para un grupo de desordenes genéticos que afectan primariamente el crecimiento celular de los tejidos neurales. Existen por lo menos 8 formas de NF, siendo las dos principales la neurofibromatosis tipo 1 (NF1) y la neurofibromatosis tipo 2 (NF2). ${ }^{1}$

La neurofibromatosis tipo 1 (NF1), también conocida como enfermedad de Von Recklinghausen, es el tipo mas común. ${ }^{1}$ Es una alteración genética relativamente frecuente, con prevalencia de 1:3000 nacimientos de acuerdo con la literatura. ${ }^{2}$ No presenta predilección por raza o sexo. ${ }^{1,3}$ La enfermedad es heredada con trazo autosómico dominante, aunque el $50 \%$ de todos los pacientes no tengan historia familiar, representando nuevas mutaciones. 4,5

La NF1 es caracterizada por manifestaciones cutáneas, nerviosas, esqueléticas y orales. ${ }^{6}$ Está principalmente asociada con la presencia de manchas café-con-leche en piel y por nódulos cutáneos. Manchas axilares (Signo de Crowe) y pigmentaciones translúcidas de coloración acastañada en el íris, conocidos como nódulos de Lisch, son encontrados en casi todos los individuos. ${ }^{5}$ Alteraciones esqueléticas también son descritas, presentándose como hipoplasias mandibulares y aumento del canal mandibular. ${ }^{6}$

Las manifestaciones orales de la NF1 son encontradas en hasta el $72 \%$ de los pacientes, ${ }^{7}$ siendo la más común el aumento de las papilas fungiformes de la lengua. ${ }^{5}$ Nódulos asintomáticos aislados, no ulcerados y con el mismo color de la mucosa son frecuentes y están localizados en el paladar, en la mucosa yugal, en el vestíbulo o en la lengua. La afectación de la mucosa alveolar es rara y encontradaa en apenas el 5\% de los casos. ${ }^{7}$ La macroglosia es observada debido a la afectación difuso de la lengua. 3,8 La asimetria facial está presente en $10 \%$ de los pacientes y se caracteriza como una hipoplasia del esqueleto facial. ${ }^{9}$

El diagnóstico de neurofibromatosis es eminentemente clínico, siendo que la aplicación de los criterios diagnósticos permite el establecimiento del mismo en la gran mayoría de los casos. ${ }^{10}$

Actualmente no existe ningún tratamiento específico para la neurofibromatosis. Las conductas consisten en acompañamiento clínico o intervención quirúrgica para resección de las lesiones neurofibromatosas cuando éstas interferieren con la funçión y estética, o cuando existan posibilidades evidentes de malignización. $3,6,8,11$

A continuación presentamos un caso de NF 1 con lesiones afectando a la mucosa gingival alveolar en la región anterior de mandíbula y en la región lingual, con necesidad de resección quirúrgica de la lesión en reborde alveolar debido a la interferencia con una adecuada higiene local.

\section{Caso clínico}

La paciente EJO, morena, sexo femenino, 23 años, fue encaminada al Servicio de Cirugía Buco-maxilo-facial de la Facultad de Odontología de Piracicaba (FOP/UNICAMP) para remoción de lesión en región lingual de dientes anteriores inferiores. La misma poseía diagnóstico clínico de neurofibromatosis.

\section{Introduction}

The term neurofibromatosis (NF) is used for a group of genetic disorders that primarily affect the cellular growth of neural tissues. At least 8 forms of NF exist. The two main forms are type 1 neurofibromatosis (NF-1) and type 2 neurofibromatosis (NF-2). ${ }^{1}$

Type 1 neurofibromatosis (NF-1), also known as Von Recklinghausen's disease, is the most common type. ${ }^{1}$ It is a relatively frequent genetic anomaly, with a prevalence of 1:3000 births reported in the literature. ${ }^{2}$ NF-1 shows no predilection for race or sex. ${ }^{1,3}$ Inheritance is autosomal dominant, although $50 \%$ of patients do not have a family history and correspond to sporadic mutations.

NF-1 is characterized by cutaneous, nervous, skeletal, and oral manifestations. ${ }^{6}$ It is associated mainly with the presence of cafe au lait spots on the skin and skin nodules. Axillary freckling (Crowe sign) and translucent, chestnut-colored pigmentation of the iris, known as Lisch nodules, are found in almost all affected individuals. ${ }^{5}$ Skeletal anomalies have been reported, such as mandibular hypoplasia and widened mandibular canal. 6

Oral manifestations are found in up to $72 \%$ of patients with NF-1,7 the most common being an increase in the fungiform papillae of the tongue. ${ }^{5}$ Isolated, unulcerated, asymptomatic nodules of the same color as the mucosa are frequent and are located in the palate, cheek mucosa, vestibule, or tongue. Involvement of the alveolar mucosa is rare, being found in only $5 \%$ of cases. ${ }^{7}$ Macroglossia is produced by diffuse tongue involvement. 3,8 Facial asymmetry is present in $10 \%$ of patients and is characterized by hypoplasia of the facial skeleton.

The diagnosis of neurofibromatosis is eminently clinical because the application of diagnostic criteria generally yields the diagnosis.

At present, there is no specific treatment for neurofibromatosis. Therapeutic strategies consist of clinical support or surgery to excise neurofibromatous lesions that interfere with function or cosmetic appearance, or present an evident risk of malignization.

We report the case of a patient with NF-1 and lesions that affected the alveolar gingival mucosa in the anterior region of the jaw and tongue. The lesion of the alveolar rim had to be removed because it interfered with oral hygiene.

\section{Clinical case}

The patient EJO, a brunette, 23-year-old woman, was referred to the Buco-Maxillo-Facial Surgery Department of the Piracicaba School of Odontology (FOP/UNICAMP) for resection of a lesion in the lingual region of the anterior lower arch. The patient had been clinically diagnosed of neurofibromatosis.

The physical examination disclosed facial asymmetry and hundreds of skin nodules scattered over her body, includ- 
Al examen físico fue observada una asimetría facial y centenas de nódulos cutáneos por todo el cuerpo incluyendo cara y cuello. (Fig. 1) Manchas café con leche estaban presentes en tronco y miembros superiores (Fig. 2).

Al examen intraoral se verificó maloclusión, diastemas, ausencias dentarias y una masa de aspecto neurofibromatoso en la región del reborde alveolar inferior, lingualmente a los incisivos. La lesión era firme e indolora a la palpación, de coloración de mucosa normal, no ulcerada, de base sésil y con cerca 2,5 cm de extensión. (Fig. 3) Debido a su tamaño y su relación con los dientes, no permitía una adecuada higiene de la región, favoreciendo el acúmulo de cálculo. La lengua también presentaba aumento de volumen, con presencia de lesión neurofibromatosa de límites difusos (Fig. 4).

Al examen radiográfico fue observado la presencia del elemento 23 retenido, asi como hipoplasia mandibular derecha (Fig. 5).

La conducta adoptada para la lesión neurofibromatosa presente en la región anterior inferior fue la excisión quirúrgica. La lesión en región lingual no fue abordada quirúrgicamente debido al hecho de que la misma no presentaba compromiso funcional o estético para la paciente. El diagnóstico de neurofibromatosis fue confirmado mediante análisis anatomopatológico (Fig. 6).

La paciente se encuentra con seis meses de seguimiento post-operatorio, sin quejas y sin señal aparente de recidiva de la lesión. Actualmente, la paciente está bajo tratamiento periodontal, con una mejora significativa de las condiciones de los tejidos de soporte local (Fig. 7).

\section{Discusión}

En el presente caso clínico se puede observar muchas características de esta enfermedad, como alteraciones cutáneas, esqueléticas y orales. Dentro de las manifestaciones cutáneas fueron notados nódulos y manchas café con leche por todo el cuerpo, cara y cuello del paciente, a través de los cuales ya fue posible establecer el diagnóstico de neurofibromatosis tipo 1.5

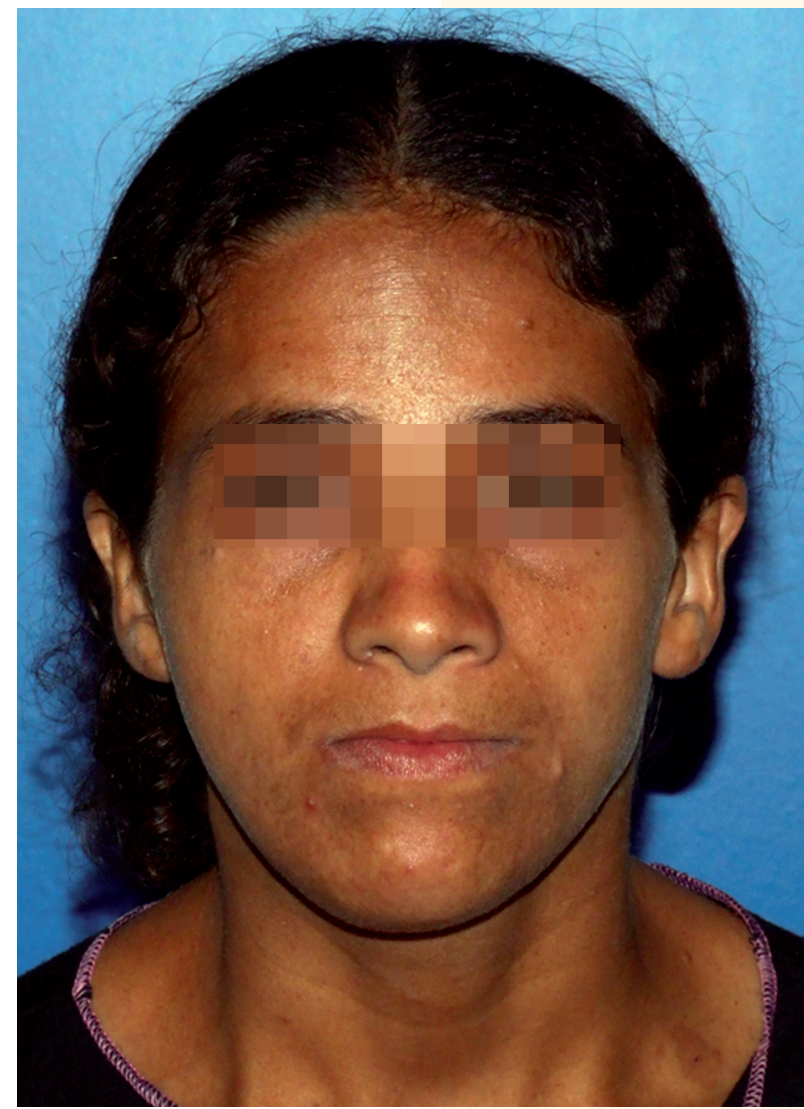

Figura 1. Fotografía frontal.

Figure 1. Frontal photograph.

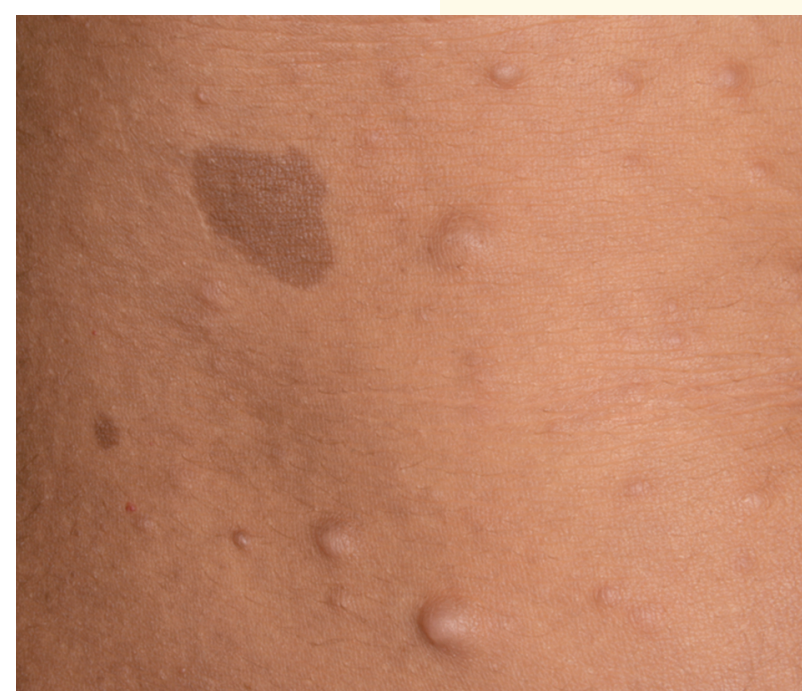

Figura 2. Mancha café-con-leche y nódulos cutáneos. Figure 2. Café au lait spot and skin nodules. ing the face and neck (Fig. 1). Café au lait spots were present on the trunk and upper limbs (Fig. 2).

The intraoral examination showed poor occlusion, diastemata, missing teeth, and a mass of neurofibroma tous appearance of the lower alveolar bridge on the lingual face of the incisor area. The lesion was firm and painless on palpation, of normal mucosal color, not ulcerated, had a sessile base, and was almost $2.5 \mathrm{~cm}$ in diameter (Fig. 3). Due to the size of the nodule and its relation with the teeth, it interfered with oral hygiene and predisposed to plaque accumulation. The tongue was enlarged and contained a diffusely limited neurofibromatous lesion (Fig. 4). On radiographic examination, retention of element 23 and right mandibular hypoplasia were observed (Fig. 5).

The strategy adopted for the neurofibromatous lesion present on the anterior lower dental arch was surgical excision. The lesion in the lingual region was not treated surgically because it did not impair the function or cosmetic appearance of the patient. The diagnosis of neurofibromatosis was confirmed by histopathologic analysis (Fig. 6).

The patient underwent six months of postoperative follow-up without registering any complaints or apparent signs of recurrence of the lesion. The patient is presently receiving periodontal treatment and the condition of the local support tissues has improved (Fig. 7).

\section{Discussion}

Many of the features of neurofibromatosis were observed in the present clinical case, such as cutaneous, skeletal, and 
Las manifestaciones orales son bien conocidas, pero muchas veces la neurofibromatosis no es por si sola diferenciada de otras alteraciones teciduales de la mucosa oral. ${ }^{12-14}$ La frecuencia de las manifestaciones orales es controvertida en la literatura. Algunos autores relatan la apariencia en apenas 4 a $7 \%$ de los casos $^{3}$ en cuanto otros sugieren que esas manifestaciones están presentes en hasta $72 \%$ de los casos. 7,9 Nódulos aislados, no ulcerados y de la misma coloración de la mucosa son notados durante el examen clínico intraoral. Generalmente están localizados en la mucosa yugal, en paladar, en cresta alveolar, en vestíbulo y en la lengua. ${ }^{3}$ Las lesiones son asintomáticas, ${ }^{8}$ y la lengua es descrita como la más afectada, ${ }^{6}$ presentándose macroglosia. En el caso descrito se observó un neurofibroma localizado en la región gingival anterior mandibular y lesión difusa en lengua, alterando su volumen. Como descrito en la literatura, la localización en gingiva es rara, y es encontrada en apenas $5 \%$ de los casos. ${ }^{8}$ En este caso, la lesión puede ser confundida con enfermedad periodontal, 14 o causar una enfermedad periodontal, ya que el crecimiento impide el acceso a las superficies dentarias, impidiendo una correcta higiene.

Pérdidas dentarias, impactaciones y mal posicionamiento dental son frecuentemente encontrados. ${ }^{12}$ Los neurofibromas en la región lingual de los incisivos pueden causar diastemas entre esos dientes. ${ }^{7}$ Esas características también fueron observadas en el caso descrito.

Durante el examen físico, fue notada una asimetría facial debido a alteraciones en crecimiento óseo de la mandíbula. El compromiso óseo es común en pacientes con neurofibromatosis, siendo descrito en 51 a $71 \%$ de los casos. ${ }^{11}$ Los hallazgos radiográficos de la región maxilofacial pueden revelar aumento del foramen y canal mandibular, densidad ósea aumentada, aumento de la dimensión de la escotadura coronoide, ${ }^{5}$ y defectos radiolúcidos. 6,11 Hipoplasias e hiperplasias óseas pueden ser encontradas en maxilar, mandíbula, hueso zigomático y en articulación temporomandibular, siendo responsables de las asimetrías faciales. ${ }^{7}$

El tratamiento de la neurofibromatosis es sintomático ya que se trata de una enfermedad de naturaleza progresiva. No hay tratamiento específico, ${ }^{3}$ siendo éste centrado en la prevención o el tratamiento de las complicaciones. ${ }^{5}$ De acuerdo con la literatura, deben

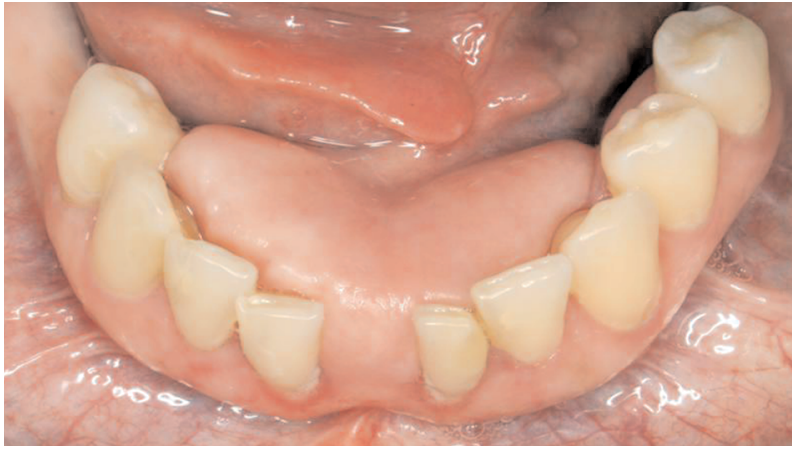

Figura 3. Lesión neurofibromatosa en región alveolar inferior. Figure 3. Neurofibromatous lesion of the lower alveolar arch.

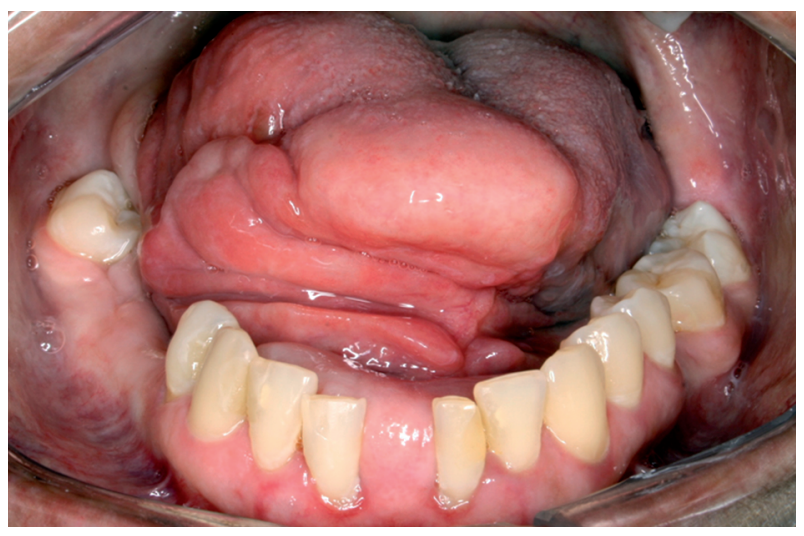

Figura 4. Aspecto de la lesión neurofibromatosa en lengua. Figure 4. Appearance of the neurofibromatous lesion of the tongue.

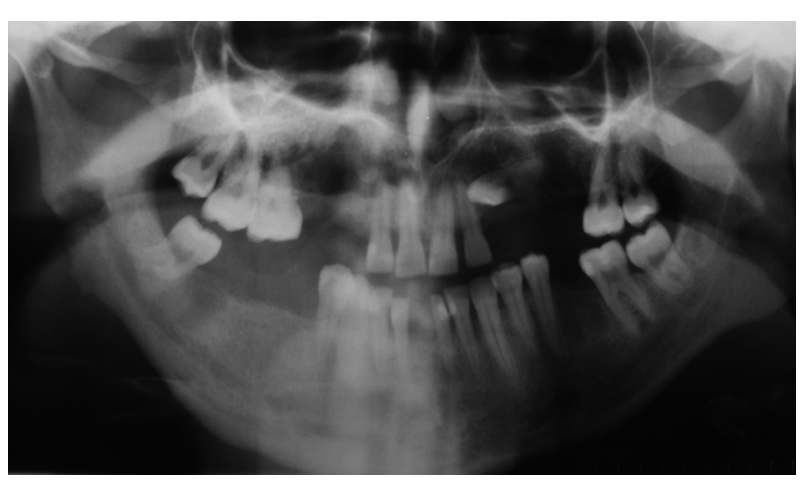

Figura 5. Radiografía panorámica. Figure 5. Panoramic radiography. oral anomalies. Cutaneous manifestations included nodules and café au lait spots over the body, face, and neck of the patient. This was the basis for the diagnosis of type 1 neurofibromatosis. ${ }^{5}$

The oral manifestations are well known, but neurofibromatosis often cannot be differentiated from other histologic abnormalities of the oral mucosa. ${ }^{12-14}$ The frequency of oral manifestations is debated in the literature. Some authors report a frequency of $4-7 \%$ of cases, ${ }^{3}$ whereas others suggest that these manifestations are present in up to $72 \%$ of cases. 7,9 Isolated, unulcerated nodules of the same color as the mucosa are detected during the intraoral clinical examination. Intraoral lesions generally are located on the cheek mucosa, palate, alveolar ridge, vestibule, and tongue. ${ }^{3}$ Lesions are asymptomatic ${ }^{8}$ and the tongue is described as the most affected structure, ${ }^{6}$ resulting in macroglossia. In the case reported, a neurofibroma was located in the anterior mandibular gingiva and a diffuse tongue lesion had caused macroglossia. As reported in the literature, the gingival location is rare, being found in a scant $5 \%$ of cases. ${ }^{8}$ Gingival lesions can be confused with periodontal disease,,$^{14}$ or cause periodontal disease, because tissue growth impedes access to dental surfaces and is an obstacle to proper oral hygiene.

Tooth loss, impaction, and dental malposition are common. ${ }^{12}$ Neurofibromas of the lingual surface of the incisor ridge can separate the teeth. ${ }^{7}$ These characteristics were also observed in our patient.

During the physical examination, facial asymmetry due to alterations in mandibular bone growth was observed. Bone involvement is common in patients with neurofibro- 
ser realizados seguimientos clínicos e intervención quirúrgica cuando las lesiones comprometan la estética o la función. ${ }^{6-}$ 8,12 En el presente caso se optó por realizar tratamiento quirúrgico, debido a las dimensiones que presentó la lesión y a la interferencia de ésta con la realización de una correcta higiene oral. Pero la lesión no fue totalmente removida debido a dificultades en establecimiento de sus límites, lo que para Cunha, ${ }^{13}$ conveniente el tratamiento quirúrgico insatisfactorio. Para Bekisz, ${ }^{15}$ la cirugía solamente debería ser realizada después del completo crecimiento de la lesión. Así, ésta seria completamente excitada y el riesgo de recidiva, minimizado.

Se pensaba que procedimientos quirúrgicos repetidos causaban malignización de la lesión. ${ }^{8}$ Hoy se sabe que eso no ocurre, lo que convierte estos procedimientos en posibles de ser realizados. ${ }^{6,15}$ Asimismo, los riesgos, las posibles complicaciones y el beneficio de esta conducta deben ser considerados antes de su ejecución.

Independiente de la realización de procedimientos quirúrgicos previos o no, existe un potencial de malignización en el $5 \%$ de los casos. ${ }^{5}$ Cuando eso ocurre, el pronóstico es desfavorable. ${ }^{3}$ De esta forma, los pacientes que presentan neurofibromatosis deben ser siempre reevaluados clínicamente para verificar el curso de la enfermedad.

\section{Conclusiones}

El caso clínico presentó manifestaciones orales de la neurofibromatosis, asi como una localización rara de neurofibroma en región lingual de los incisivos inferiores. El abordaje quirúrgico de las lesiones intrabucales asociadas a la neurofibromatosis permite el restablecimiento funcional $y$, como fue descrito, convierte en posible la realización de una correcta higiene oral. Los neurofibromas intraorales deben ser constantemente seguidos debido al riesgo de malignización o recidiva, con compromiso funcional o estético del paciente.

\section{Bibliografía}

1. Friedman JM. Epidemiology of neurofibromatosis type 1. Am J Med Genet 1999;89:1-6.

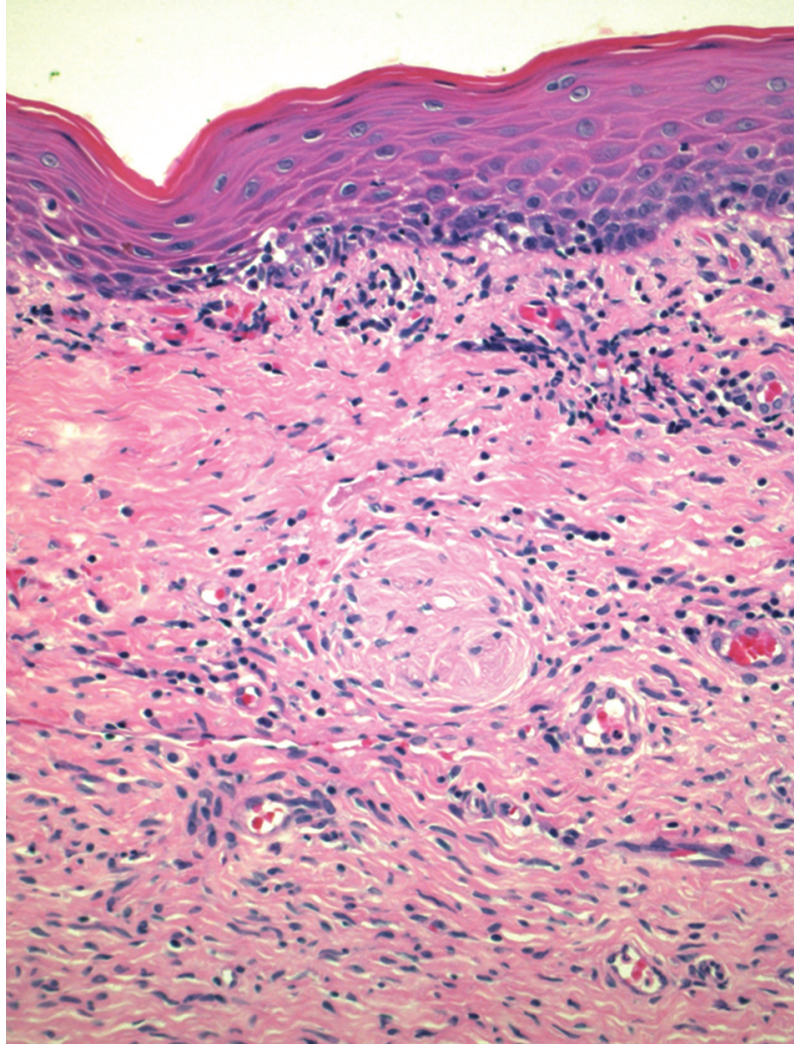

Figura 6. Aspecto microscópico de la lesión.

Figure 6. Microscopic appearance of lesion.

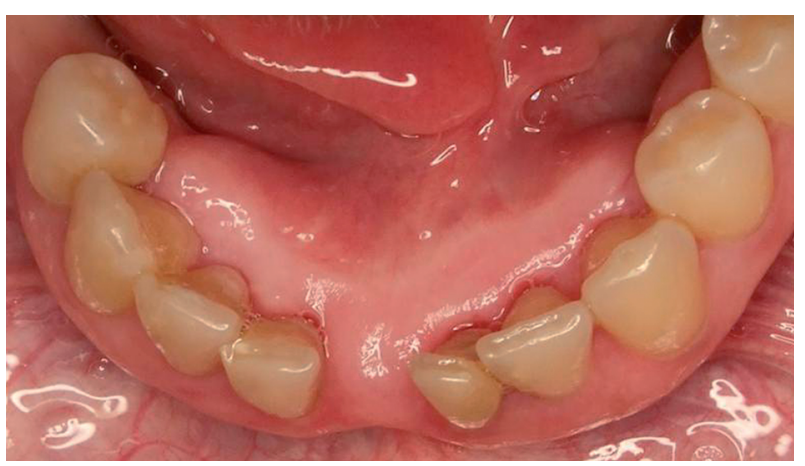

Figura 7. Aspecto clínico después de la resección de la lesión. Figure 7. Clinical appearance after removal of the lesion. matosis (51-71\% of cases). ${ }^{11}$ The radiographic findings in the maxillofacial region may reveal an enlarged mandibular foramen and canal, increased bone density, a widened coronoid notch, 5 and radiolucent defects.6,11 Bone hypoplasia and hyperplasia may be seen in the maxilla, mandible, and malar bones and temporomandibular joint, which cause facial asymmetry. ${ }^{7}$

The treatment of neurofibromatosis is little more than symptomatic because the disease is progressive. There is no specific treatment. ${ }^{3}$ Therapy is designed to prevent or manage complications.5 According to the literature, clinical follow-up should be conducted and surgery performed when the lesions compromise the patient's function or cosmetic appearance. 6,7,8,12 In the present case, surgical treatment was chosen because of the dimensions of the lesion and its interference with proper oral hygiene. However, the lesion was not fully resected due to difficulties in establishing its limits. For Cunha, ${ }^{13}$ this makes surgery unsatisfactory. Bekisz ${ }^{15}$ claims that surgery should be performed only after the lesion has grown completely. This allows the lesion to be completely excised and reduces the risk of recurrence.

It was once thought that repeated surgical procedures were responsible for malignization of the lesions. ${ }^{8}$ Now it is known that this is not the case, which makes these procedures acceptable.6,15 The risks, possible complications, and benefits of a surgical strategy must be considered before intervening.

Regardless of whether of not previous surgical procedures have been performed, malignization affects $5 \%$ of cases. ${ }^{5}$ When malignization occurs, the prognosis is unfavorable. ${ }^{3}$ Consequently, patients with neurofibromatosis must always 
2. Cotran RS, Kumar V, Robbins SL. Pathologic Basis of Disease, 5th ed. Philadelphia: W.B. Saunders Company, 1994.

3. Shafer WG, Hine MK, Levy BM. Tratado de Patologia Bucal. $4^{\text {a }}$ ed. Rio de Janeiro: Guanabara Koogan, 1987.

4. Friedrich RE, Giese M, Schmelzle R, Mautner VF, Scheuer HA. Jaw malformations plus displacement and numerical aberrations of teeth in neurofibromatosis type 1: a descriptive analysis of 48 patients based on panoramic radiographs and oral findings. J Craniomaxillofac Surg 2003;31:1-9.

5. Neville BW, Damm DD, Allen CM, Bouquot JE. Patologia Oral e Maxilofacial. 2 ${ }^{\mathrm{a}}$ ed. Rio de Janeiro: Guanabara Koogan, 2004.

6. Holtzman L. Radiographic manifestation and treatment considerations in a case of multiple neurofibromatosis. J Endod 1998;24:442-3.

7. Shapiro SD, Abramovitch K, Van Dis ML, Skoczylas LJ, Langlais RP, Jorgenson RJ, y cols. Neurofibromatosis: oral and radiographic manifestations. Oral Surg Oral Med Oral Pathol 1984;58:493-8.

8. Epstein JB, Schubert MM, Hatcher DC. Multiple neurofibromatosis. Report of a case. Oral Surg Oral Med Oral Pathol 1983;56:560-2.

9. D'Ambrosio JA, Langlais RP, Young RS. Jaw and skull changes in neurofibromatosis. Oral Surg Oral Med Oral Pathol 1988;66:391-6.

10. Gutmann DH, Aylsworth A, Carey JC, Korf B, Marks J, Pyeritz RE, y cols. The diagnostic evaluation and multidisciplinary management of neurofibromatosis 1 and neurofibromatosis 2. JAMA 1997;278:51-7.

11. Vincent SD, Williams TP. Mandibular abnormalities in neurofibromatosis. Case report and literature review. Oral Surg Oral Med Oral Pathol 1983;55:253-8.

12. Bongiorno MR, Pistone $G$, Arico M. Manifestations of the tongue in neurofibromatosis type 1. Oral Dis 2006;12:125-9.

13. Cunha KS, Barboza EP, Dias EP, Oliveira FM. Neurofibromatosis type I with periodontal manifestation. A case report and literature review. Br Dent / 2004;196: 457-60.

14. Powell CA, Stanley CM, Bannister SR, McDonnell HT, Moritz AJ, Deas DE. Palatal neurofibroma associated with localized periodontitis. J Periodontol 2006; 77:310-5.

15. Bekisz O, Darimont F, Rompen EH. Diffuse but unilateral gingival enlargement associated with von Recklinghausen neurofibromatosis: a case report. / Clin Periodontol 2000;27:361-5. be followed up clinically to evaluate the course of the disease.

\section{Conclusions}

Our patient had oral manifestations of neurofibromatosis, including an uncommon location of neurofibroma on the lingual face of the lower incisor arch. A surgical approach to oral lesions associated with neurofibromatosis allows function to be restored and makes correct oral hygiene possible, as in our case. Intraoral neurofibromas must always be followed up because of the risk of malignization or recurrence, in addition to functional or cosmetic impairment of the patient. 